УДК 351: 332.1: $330.322+502 / 504$

Ю. В. Орловська,

д. е.н., професоркафедри міжнародної економіки та публічного управління $і$ адміністрування, Придніпровська державна академія будівництва та архітектури, м. Аніпро

ORCID ID: 0000-0002-5915-4261

O. О. КВактун,

к. е.н., дочент кафедри міжнародної економіки та публічного управління і адміністрування, Придніпровська державна академіл будівництва та архітектури, м. Аніпро

ORCID ID: 0000-0002-7263-8105

O. O. Kaxobuч,

к. держ. упр., дочент кафедри міжнародної економіки та публічного управління і адміністрування, Придніпровська державна академія будівництва та архітектури, м. Аніпро

ORCID ID: 0000-0003-2100-1232

K. B. Аригола,

аспірант, асистент кафедри міжнародної економіки та публічного управління і адміністрування, Придніпровська державна академіл будівництва та архітектури, м. Аніпро

ORCID ID: 0000-0001-7928-6408

DOI: $10.32702 / 2306-6814.2021 .16 .70$

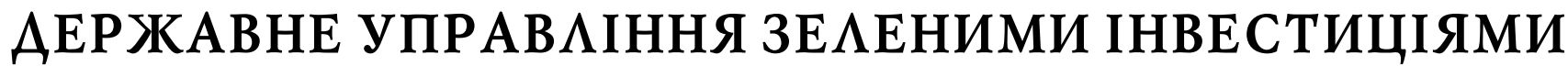 ЯК ФАКТОР СТААОГО РОЗВИТКУ РЕГІОНІВ
}

\author{
Yu. Orlovska, \\ Doctor of Economic Sciences, Professor of the Department of International Economics and Public Administration, \\ Prydniprovska State Academy of Civil Engineering and Architecture, Dnipro \\ O. Kvaktun, \\ $\mathrm{PhD}$ in Economics, Associate Professor of the Department of International Economics and Public Administration, \\ Prydniprovska State Academy of Civil Engineering and Architecture, Dnipro \\ O. Kakhovich, \\ $\mathrm{PhD}$ in Public Administration, Associate Professor of the Department of International Economics and Public \\ Administration, Prydniprovska State Academy of Civil Engineering and Architecture, Dnipro \\ K. Dryhola, \\ Postgraduate student, Assistant of the Department of International Economics and Public Administration, \\ Prydniprovska State Academy of Civil Engineering and Architecture, Dnipro
}

\section{PUBLIC ADMINISTRATION OF GREEN INVESTMENTS AS A FACTOR OF SUSTAINABLE DEVELOPMENT OF REGIONS}

\footnotetext{
Метою цієї роботи було обгрунтування механізмів зеленого інвестиційного забезпечення сталого розвитку регіонів за рахунок ефективних механізмів державного управління. Встановлено важливість досягнення сталого розвитку для країн світу в умовах сучасних трансформацій та вагому роль регіонів у цьому процесі. Надано визначення сталого розвитку регіону як цілісної соціо-еколого-економічної системи. Встановлено основні інструменти зеленої фінансово-економічної політики держави та надано визначення зелених інвестицій.

Запропоновано формувати державне управління зеленими інвестиціями на основі логікосемантичної моделі "тиск-стан-реакція". Зазначено, що "тиск" відображається показником справжніх заощаджень регіону. Проаналізовано динаміку валових накопичень та справжніх заощаджень України та зроблено припущення, що схожі тенденції відбуваються і на регіональному рівні. Проаналізовано динаміку капітальних інвестицій в охорону навколишнього середовища регіонів України.
} 
Встановлено, що "стан" відображається індикаторами глобальних цілей сталого розвиткута відображає фактичний рівень незворотніх змін та наближення території до сталого розвитку. "Реакція" має формуватись на основі SWOT-аналізу територій та подальшій розробці матриці зелених інвестицій.

Зазначена модель має виступати базисом державного управління зеленими інвестиціями та впроваджуватись у регіональні стратегії розвитку в рамках зеленої регіональної політики.

The purpose of this study was to substantiate the mechanisms of green investment support for sustainable development of regions through effective mechanisms of public administration. The importance of achieving sustainable development for the countries in the conditions of modern transformations as well as the important role of regions in this process have been established. The definition of sustainable development of the region as a holistic socio-ecological-economic system has been given. The main instruments of the green financial and economic policy of the state have been established and the definition of green investments has been given.

It has been suggested to form the state management of green investments on the basis of the logical-semantic model "pressure-state-reaction". It has been noted that the "pressure" is reflected in the real savings of the region. The dynamics of gross savings and real savings of Ukraine has been analyzed and it is assumed that similar trends occur at the regional level. The dynamics of capital investments in environmental protection of the regions of Ukraine has been analyzed.

It has been established that the "state" is reflected in the indicators of global goals of sustainable development and reflects the actual level of irreversible changes and the approach of the territory to sustainable development. The "reaction" should be formed on the basis of SWOT-analysis of territories and further development of the matrix of green investments.

The existing model of public administration of green investments needs to be changed, namely in the basis of decision-making on environmentally friendly measures and finding sources of funding. In Ukraine there is a significant disproportion between economic and "real" growth, which is reflected in the indicator of real savings, which is calculated as gross savings converted into environmental damage. In addition, despite a moderate increase in investment in environmental measures, their volume remains very small at no more than $1.5 \%$ of the GRP.

That is why it has been suggested to carry out public management of green investments on the basis of the logical-semantic model of "pressure-state-reaction". This model makes clear the region's potential for sustainable development, its actual level and the formulation of priorities for green investments and program activities, as well as the sources of their funding. Thus, this model provides both a tool for assessing the actual state of development of regions and the formation of development priorities with further forecasting and monitoring of the effectiveness of implemented actions.

The model should serve as a basis for public management of green investments and be implemented in regional development strategies within the framework of green regional policy.

КлючоВі слоВа: зелені інВестиціі, держаВне упраВління, зелена економіка, зелене зростання, зелена політика, сталий розВиток, регіони.

Key words: green investments, public administration, green economy, green growth, green policy, sustainable development, regions.

\section{ПОСТАНОВКА ПРОБАЕМИ}

Вумовах глобальних перетворень сучасності та курсу людства на сталий розвиток, важливим завданням кожної країни постає фрормування ефрективної стратегії досягнення глобальних цілей сталого розвитку, що має бути реалізовано за рахунок державного управління соціально-економічними процесами. Основним фрінансовим механізмом досягнення сталого розвитку мають виступати зелені інвестиції, якіє каталізатором зеленого зростання і сприяють встановленню зеленої економіки, в рамках якої стає можливим досягнення глобальних цілей сталого розвитку. Крім того, орієнтиром державного управління має виступати регіональна політика, яка враховує особливості розвитку окремих територій всередині держави. Саме регіональний підхід дозволяє ефективно використовувати сильні сторони окремих регіонів та спрямовувати зусилля на диспропорції розвитку в залежності від їх фрункціональної природи. Саме тому пошук ефективних механізмів державного управління зеленими інвестиціями є пріоритетним питанням для розвитку кожної країни на шляху досягнення глобальних цілей сталого розвитку в умовах зеленої економіки. 


\section{AHА $\Lambda$ I ОСТ АHHIX АОС $\triangle \mathrm{IAЖEHЬ}$ І ПУБ $\Lambda$ ІКАЦІЙ}

Проблемам пошуку ефективних механізмів державного управління зеленими інвестиціями присвятили свої праці А.С. Кумачова, Ю.О. Ульянченко, І.М. Вахович, Ю.О. Франчук, Н.О. Комісарук, В.М. Рублик, С.М. Домбровська, О.М. Клименко, А.С. Ігнатченко, Б.Л. Ковальов та інші. При цьому в дослідження теоретичного бекграунду сталого розвитку регіонів та його забезпечення засобами державного управління внесли значний внесок І.В. Горяна, В.М. Ільченко, О.Б. Ватченко, О.Ю. Бобровська, Л.Г. Мельник, О.В. Кубатко, В.Т. Лагно, А.І. Сухоруков, С.В. Волик, В.С. Дяченко, І.С. Благун, Л.І. Сисак, О.О. Солтисік та інші.

Проте, попри вагомий доробок вчених, на сьогодні досі не існує загально визначеного механізму впровадження, моніторингу та оцінки зелених інвестицій. Крім того, залишаються недостатньо дослідженими питання побудови державних зелених інвестиційних стратегій задля досягнення глобальних цілей сталого розвитку.

\section{META CTATTI}

Метою наукового дослідження є обгрунтування механізмів зеленого інвестиційного забезпечення сталого розвитку регіонів за рахунок ефективних механізмів державного управління.

\section{ВИК ААА ОСНОВНОГО МАТЕРІААУ АОС $А$ ЖЖЕННЯ}

Починаючи з 60-70-тих років XX ст., людство почало усвідомлювати важливість екологічної компоненти розвитку. Це було спричинено появою та посиленням глобальних екологічних проблем, які з'являлись на тлі екстенсивного економічного зростання. В цей період у наукових та урядових колах з'являються теорії щодо гармонізації економічного та соціального розвитку та посилюється занепокоєність проблемами навколишнього середовища та виснаженням природніх ресурсів. Результатом розвитку наукових теорій стає виникнення поняття "сталості".

Безпосередньо термін "сталий розвиток" було надано в доповіді Комісії Брундтланд "Наше спільне майбутнє" 1989 р. [1], в якій зазначалось, що сталий розвиток - це такий тип економічного зростання, який не перешкоджає майбутнім поколінням задовольняти їх власні потреби і грунтується на функціональній системі з трьох елементів - економіка, екологія, соціум.

Сталий розвиток став основним курсом для всього світу і елементом стратегій державного управління. У 2015 р. відбувся Саміт з питань сталого розвитку в НьюЙорку, на якому було представлено 17 глобальних цілей і встановлено, що вони мають бути досягнені до 2030 р. У відповідь різні країни світу розробили національні стратегії сталого розвитку, які ставили на меті досягнення зазначених цілей з урахуванням особливостей розвитку країн. При цьому стало зрозумілим, що досягнення сталого розвитку у будь-якій країні неможливо без досягнення сталого розвитку її окремих регіонів. Кожен регіон має багато специфрічних рис, які визначають необхідність пошуку власних стратегічних моделей переходу до сталості. Ефективне використання "природного капіталу" кожного регіону є запорукою збіль- шення національного багатства, життєзабезпечення населення, підтримки геосистем та збереження довкілля. Тому соціо-еколого-економічна система регіону $\epsilon$ сталою у випадку, якщо в результаті зіткнення природних, виробничих, соціальнихй інших часткових інтересів можливо досягнення деякого компромісу в процесі виконання кожної з перерахованих підсистем власної індивідуальної мети [2].

У цьому контексті "сталий розвиток регіону - це територіально організована, динамічна взаємодія підсистем сукупного капіталу регіону (природного, виробничого та людського), регулювання якою дозволяє протистояти різким коливанням зовнішньої та внутрішньої кон'юнктури, зменшує територіальну асиметрію розвитку та зміцнює сучасний й майбутній потенціал відтворення як на регіональному, так і на національному рівнях" [3].

На сьогодні глобальний розвиток відбувається 3 курсом на "озеленення" суспільно-господарських процесів на всіх територіальних рівнях і має на меті досягнення зеленої економіки, як такої системи, "...в основі якої знаходяться зелені інновації шостого технологічного укладу, які мають бути реалізовані в господарських процесах на всіх рівнях в умовах зеленого зростання, забезпечуючи ефективне використання природного капіталу, що характеризується низьким рівнем матеріало - та ресурсомісткості за рахунок підвищення рівня розвитку людського капіталу задля досягнення глобальних цілей сталого розвитку" [4].

Тобто зелена економіка є економічною системою в межах якої стає можливим досягнення глобальних цілей сталого розвитку і яка ставить на меті зменшення викидів вуглецю в атмосферне повітря, енерго-та ресурсоефективність економічних процесів, соціальний добробут та зменшення втрат екосистем. Драйвером зеленої економіки виступає зелене зростання, яке виражається через розвиток зеленого сектору економіки внаслідок зеленого інвестування. До зеленого сектору відносять сільське господарство, зелене будівництво, альтернативну енергетику, зелені фрінанси, рибальство, лісове господарство, інформаційні технології, зелене виробництво, метали та мінерали, зелений туризм, зелений транспорт, менеджмент відходів, менеджмент водних ресурсів [5].

У свою чергу зелене зростання забезпечується зеленою політикою держави в рамках Глобального зеленого нового курсу (Global Green New Deal), що спирається на адміністративні та фрінансові інструменти. Оскільки основним завданням сталого розвитку регіону є збалансоване відтворення всіх підсистем суспільного капіталу регіону, інвестиції й інвестиційна діяльність, що безпосередньо фрормують подібні відтворювальні процеси нового екологоузгодженого змісту, мають бути досліджені особливо ретельно. Зелені інвестиції $є$ основою фінансових інструментів зеленої політики держави, які у довгостроковій перспективі формують базис для досягнення глобальних цілей сталого розвитку.

У цьому контексті зелені інвестиції - це такий тип інвестування, який здійснюється в зелені сектори економіки, забезпечує довготривале зелене зростання, що виражається у низькому рівні матеріало- та ресурсомісткості й одночасному високому рівні продуктивності 


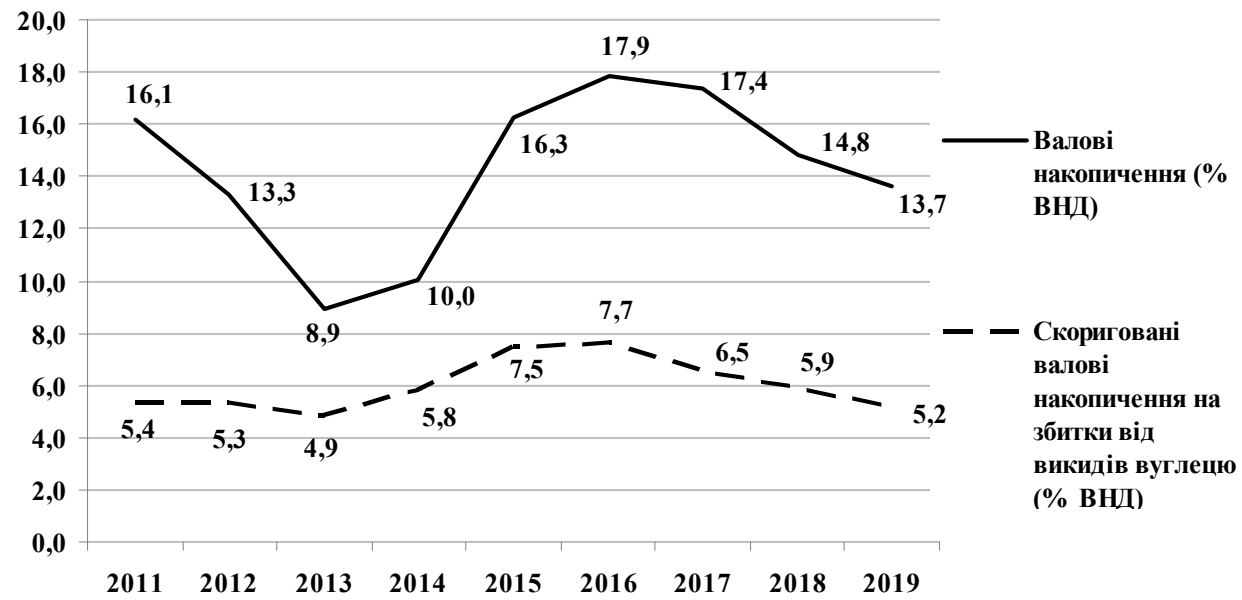

\section{Рис. 1. Динаміка валових накопичень та валових накопичень сконвертованих на збитки від викидів вуглецю в Україні, \% ВНД, 2011-2019 рр.}

Джерело: побудовано авторами за [7].

трудових ресурсів, що забезпечується інклюзивністю та створенням нових зелених робочих місць.

Зелені інвестиції $є$ одним з елементів фрінансово-економічної політики розвитку зеленої економіки, яка характеризуються такими інструментами як впровадження стандартів ESG (Environmental, Social and Governance Criteria), зелені та інклюзивні кредитні політики, зелені облігації, державні інвестиційні фронди з пріоритетністю на зелені технології, зелені фондові індекси (MSCI World ESG Index, FTSE4Good, NYSE Euronext Vigeo index family, Dow Jones Sustainability Index), зелені кредитні рейтинги, зелене страхування, зелені пенсійні фонди, зелені грантові проєкти міжнародних організацій [6].

Для ефрективного розвитку зелених інвестицій на регіональному та субрегіональному рівні необхідно сформувати модель державного регулювання інвестиційними процесами, яка б включала в себе аналіз існуючих тенденцій, впровадження регулюючих заходів, а також контроль та моніторинг результатів. У цих умовах доцільно буде використовувати структуру логіко-семантичної моделі "тиск-стан-реакція", яка фрактично ілюструє звичну послідовність регулюючих функцій будь-якого рівня управління: програма дій, оцінка її результативності, коригування. Якщо такий структурно-логічний підхід застосувати як "модель дій" на регіональному рівні, це утворить ясну послідовність планово-регулюючих заходів осіб, що приймають рішення. Необхідно тільки обгрунтувати перелік вихідних індикаторів та спосіб їхнього використання в розрахунках інтегрованих показників. Особливо важливим у цьому аспекті представляється обгрунтування комплексних соціальних, економічних та екологічних оціночних параметрів, які дають повне уявлення про об'єкт дослідження та параметри його розвитку.

Комплексним інтегральним показником "тиску" на соціально-економічну систему регіону, що дає йй імпульс та переводить у новий стан, $є$ індикатор "справжні заощадження". За допомогою цього показника вимірюються реальні "екологоузгоджені" стимули економічного зростання, а саме: обсяги капітальних вкладень за період, зменшені на розмір збитків, що завдані навколиш- ньому середовищу та здоров'ю людей. Саме такий показник максимально відображає сутність зеленого інвестування та надає можливість моніторингу та оцінки його ефективності.

Показник "стану" суспільної системи регіону пропонується вимірювати за допомогою індикаторів глобальних цілей сталого розвитку.

Показник "реакція" суспільної системи представляє собою матрицю специфічних, зорієнтованих за групами територій, інвестиційних пріоритетів та заходів; та має якісний та кількісний вимір. Якісний вимір реалізується через SWOT-аналіз вихідних даних розвитку територіальної системи та відтворювальних пріоритетів реальних екологічних інвестицій. Кількісний вимір фрормується на основі прогнозних даних щодо змін компонентів справжніх регіональних заощаджень та динаміки самого показнику.

Таким чином, у системі управління сталим регіональним розвитком ком-плексний аналіз його стану та динаміки відбувається в рамках логіко-семантичної моделі "тиск - стан - реакція" і має своє наповнення:

1) у частині важелів розвитку (відтворюючих чинників) - за рахунок використання показнику справжніх заощаджень;

2) у частині оцінки стану (рівня) сталого розвитку за рахунок використання індексу глобальних цілей сталого розвитку.

3) що ж до наповнення складової "реакція", тут має бути задіяний стратегічний чинник управління інвестиційними процесами в регіоні, причому ці інвестиційні процеси мають бути екологічноорієнтованими, тобто формуватись на основі зелених інвестицій.

Вихідним завданням державного регулювання зеленого інвестування $€$ форорування есрективних важелів, які мають бути сорормовані на основі аналізу справжніх регіональних заощаджень. На загальнонаціональному рівні існує значна диспропорція між рівнями валових накопичень та справжніх заощаджень. За даними Світового Банку [7] в Україні спостерігається тенденція до значного відриву валових накопичень від справжніх заощаджень, що виражаються як валові накопичення сконвертовані на збитки від викидів вуглецю (рис. 1). 


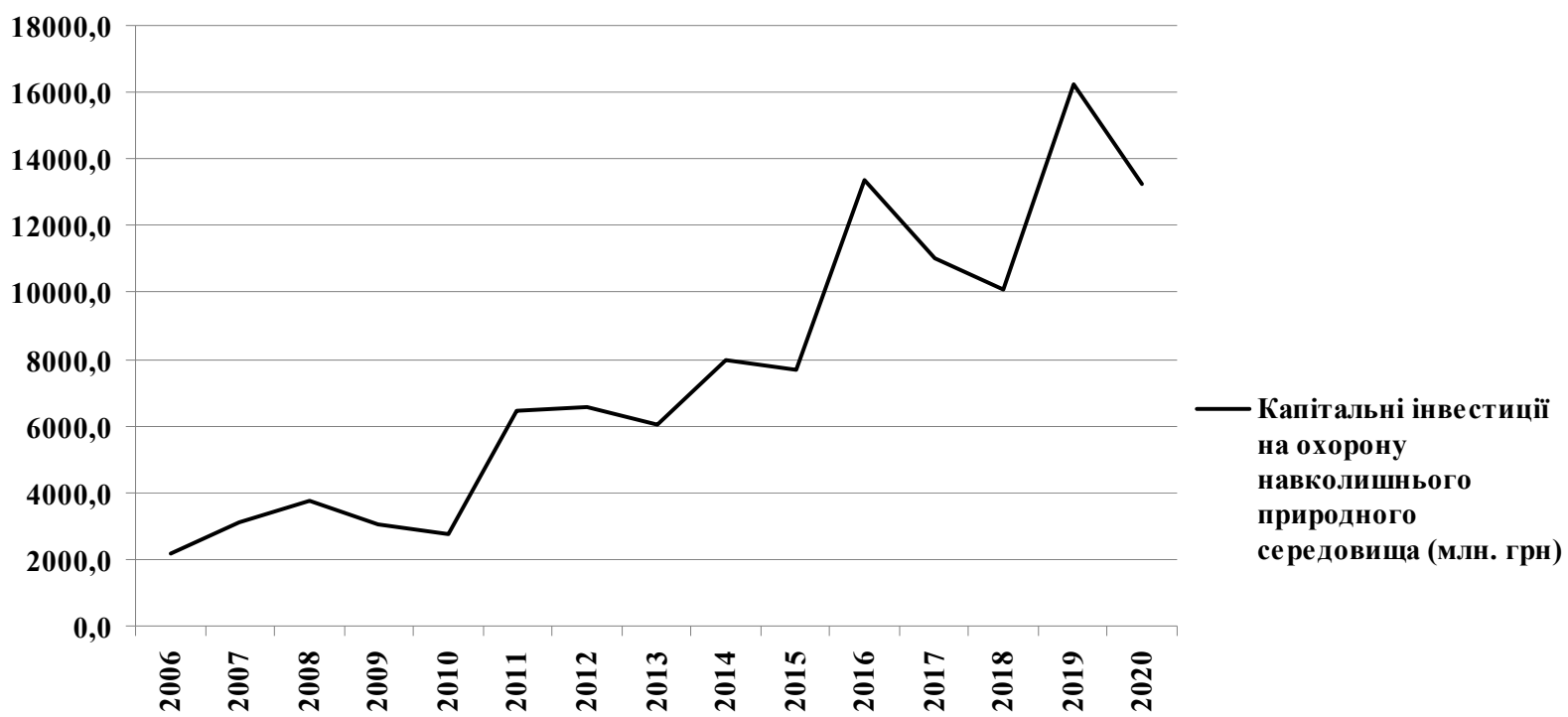

Рис. 2. Динаміка обсягу капітальних інвестицій на охорону навколишнього природного середовища в Україні, тис. грн, 2011-2020 рр.

Джерело: побудовано авторами за [8].

Очевидно, що подібна закономірність має спостерігатися й для мезо-рівня національної економіки, в т.ч. для регіонів України. Тому, виходячи з аналізу довгострокових тенденцій валових накопичень та справжніх заощаджень України, можемо зробити припущення, що поведінка подібних показників на регіональному рівні $\epsilon$ відповідною.

У свою чергу за цей період відбулось збільшення капітальних інвестицій на охорону навколишнього природного середовища з 6451034,6 тис. грн у 2011 р. до
13239649,8 тис. грн у 2020 р. (рис. 2). При цьому варто зазначити, що у 2020 р. обсяги інвестування зменшились майже на $19 \%$ відносно 2019 р.

Прот, показним індикатором кожного окремого регіону $є$ саме обсяг капітальних інвестицій як відсоток від ВРП. У регіональному розрізі лідерами за показником капітальних інвестицій на охорону навколишнього природного середовища у відсотках від ВРП є Донецька, Дніпропетровська, Запорізька, Миколаївська, Харківська та Івано-Франківська області (рис. 3).

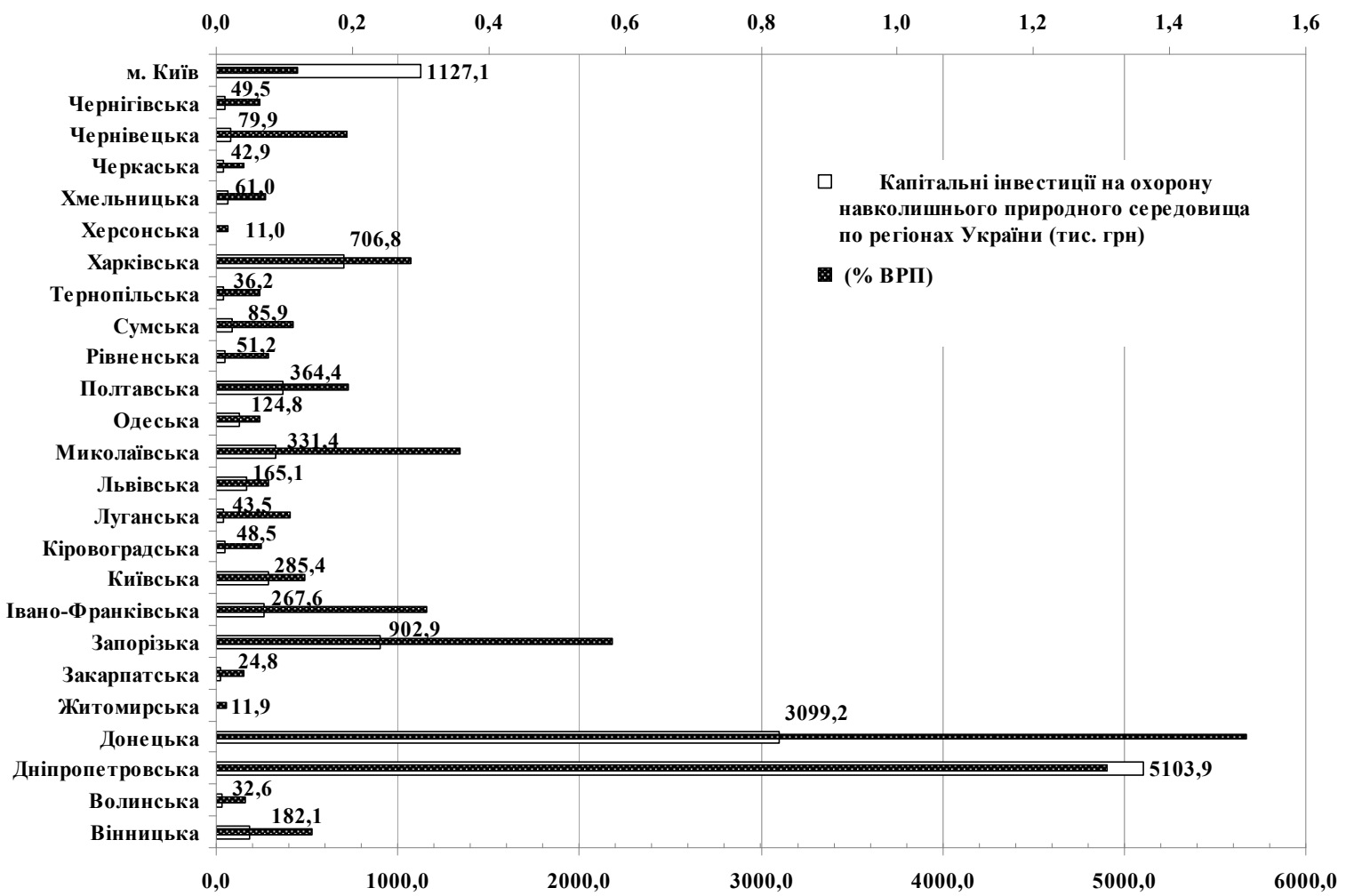

Рис. 3. Динаміка обсягу капітальних інвестицій на охорону навколишнього природного середовища регіонів України, тис. грн, \% ВРП, 2019 р.

Джерело: побудовано авторами за [8]. 
Необхідно зазначити, що відсоток інвестування дуже малий. Так, регіони лідери інвестують в охорону навколишнього природного середовище лише близько 0,5-1,5 \% від ВРП, тоді як інші регіони інвестують менше $0,5 \%$. Це демонструє відсутність пріоритетності у зелених інвестиціях, які коригують диспропорції соціоеколого-економічної системи регіону.

Планово-регулюючі заходи зеленого інвестування у регіонах мають спиратись не тільки на аналіз потенціалу сталого розвитку (який представлено показником справжніх заощаджень), але й на його фрактичний рівень, який може бути представлений індикаторами глобальних цілей сталого розвитку [9]. Так станом на 2021 р. Україна посідає 36 місце з 165 країн світу за Індексом цілей сталого розвитку [10] і демонструє тенденцію до підвищення показника. При цьому високу ймовірність досягнення мають цілі 1 (подолання бідності), 3 (міцне здоров'я і благополуччя), 4 (якісна освіта), 5 (гендерна рівність). Позитивну динаміку, яка потребує певного прискорення демонструють цілі 2 (подолання голоду, розвиток сільського господарства), 6 (чиста вода та належні санітарні умови), 8 (гідна праця та економічне зростання), 16 (мир, справедливість та сильні інститути). Слабку позитивну динаміку, яка потребує активного втручання держави демонструють цілі 7 (доступна та чиста енергія), 11 (сталий розвиток міст і громад), 12 (відповідальне споживання та виробництво), 17 (партнерство заради сталого розвитку). Від'ємну динаміку та низьку ймовірність досягнення демонструють цілі 9 (промисловість, інновації та інфрраструктура), 10 (скорочення нерівності), 13 (пом'якшення наслідків зміни клімату), 14 (збереження морських ресурсів), 15 (захист та відновлення екосистем суші). Саме останні цілі мають стати пріоритетами розвитку національної стратегії сталого розвитку на загальнодержавному та регіональному рівнях.

Виявлення тенденцій щодо потенціалу та стану сталого розвитку дає науково-практичне підгрунтя розробки системи заходів зелених інвестицій. Очевидно, що ця система заходів має визначатися певними стратегічно-інвестиційними пріоритетами, розробленими з метою зменшення рівня розбалансованості сталого розвитку та зростання його потенціалу.

Базовим кроком щодо розробки такого роду стратегічних планів-програм $\epsilon$ визначення специфічних рис, особливостей груп територій щодо можливостей підсистем їхнього сукупного капіталу формувати загальний сталий розвиток регіону. Зручним інструментом, що дозволяє вирішити таке завдання, $є$ метод SWOT-аналізу, який все частіше використовується як інструмент стратегічного планування.

Наступним кроком стратегічного планування $€$ розробка програми заходів зелених інвестицій (які мають бути структуровані у вигляді матриці зелених інвестицій), виявлення прогнозної результативності їхнього впровадження, організації механізму формування

\begin{tabular}{|c|c|}
\hline $\begin{array}{c}\text { СТАН } \\
\text { Оцінка індикаторів } \\
\text { глобальних цілей } \\
\text { сталого розвитку регіону } \\
\text { як показника } \\
\text { незворотніх змін у } \\
\text { регіональній системі та } \\
\text { ступеня наближеності до } \\
\text { сталого розвитку }\end{array}$ & $\begin{array}{c}\text { РЕАКЦІЯ } \\
\text { SWОТ-аналіз } \\
\text { інвестиційних } \\
\text { пріоритетів регіону та } \\
\text { формування матриці } \\
\text { зелених інвестицій, що } \\
\text { має характеризуватись } \\
\text { комплексом } \\
\text { еколого-орієнтованих } \\
\text { заходів з урахуванням } \\
\text { особливостей розвитку } \\
\text { регіону та джерелами їх } \\
\text { фінансування }\end{array}$ \\
\hline
\end{tabular}

РЕАКЦІЯ

SWОТ-аналіз пріоритетів регіону та формування матриці зелених інвестицій, що xapariepusyar еколого-орієнтованих сахов з урахуванням регіону та джерелами ї фінансування
Рис. 4. Схема моделі державного управління зеленими інвестиціями регіону на основі моделі "тиск-стан-реакція"

озробка.

фрінансових потоків з різних джерел для імплементації системи зелених інвестицій в довгострокову економічну політику в регіонах.

Таким чином, державне управління зеленими інвестиціями має здійснюватись за схемою "тиск-стан-реакція" (рис. 4) і застосовуватись на регіональному рівні враховуючи специфіку та особливості розвитку кожного окремого регіону.

Зазначена логічна структура має бути основою стратегій регіонального розвитку та виступати базисом формування зелених інвестиційних процесів. Реалізація зазначених заходів потребує висококваліфікованих кадрів, які мають володіти достатнім рівнем знань та практичної підготовки у сорері державного управління та екологічного менеджменту. Тому фундаментальною основою успішності регулювання виступає інтелектуальний капітал регіону.

Ключове завдання регулювання інвестиційної складової регіонального розвитку полягає в тому, щоб за рахунок активних структурних змін в інвестиційній діяльності вишукувати, формувати і концентрувати на регіональному рівні інвестиційні ресурси різних джерел походження та направляти їх на рішення найбільш значущих, актуальних і невідкладних проблем регіону. Вирішення цього завдання можливо за рахунок узгодження системи заходів регіональної зеленої політики держави з тими, що мають розроблятися на рівні регіону як елементи стратегічної інвестиційної ініціативи.

\section{ВИСНОВКИ}

На сьогодні існуюча модель державного управління зеленими інвестиціями потребує змін, а саме в основі прийняття рішень щодо екологічно орієнтованих заходів та пошуку джерел їх фрінансування. Як показав аналіз, на сьогодні в Україні існує значна диспропорція між економічним та "реальним" зростанням, яке відображається показником справжніх заощаджень, що обчислюється як валові накопичення сконвертовані на збитки навколишнього середовища. Крім того, попри помірне зростання обсягів інвестування в природоохоронні заходи, їх обсяг залишається дуже незначним і становить не більше 1,5 \% від ВРП регіону.

Взаємоузгоджене відтворення підсистем агрегованого суспільного капіталу регіону потребує най- 
більшої уваги науково-прикладного рівня, оскільки саме воно закладає основу справжнього суспільного добробуту (ефективна економіка, здорова екологія та творча особистість). Зелені інвестиційні процеси, що $є$ основою відтворення агрегованого капіталу регіону, потребують у такому контексті ретельного дослідження суті та форм реалізації. Таким чином зелене інвестування відображає територіально узгоджені капітальні вкладення, що спрямовуються на створення прибуткових основних зелених фондів, у процесі виробництва та експлуатації яких: зменшується використання природних ресурсів і пом'якшується (чи ліквідується) негативний вплив на довкілля та здоров'я людини.

Саме тому запропоновано здійснювати державне управління зеленими інвестиціями на основі логіко-семантичної моделі "тиск-стан-реакція". В рамках ціє моделі стає зрозумілим потенціал регіону до сталого розвитку, його фактичний рівень та формулювання пріоритетів зелених інвестицій й програмних заходів, а також джерел їх фінансування. Таким чином, зазначена модель надає як інструмент оцінки фрактичного стану розвитку регіонів, так і формування пріоритетів розвитку з подальшим прогнозуванням та моніторингом результативності впроваджених дій. Зазначена модель має бути фундаментальною основою стратегічного розвитку регіонів та становити основу зеленої регіональної політики.

\section{Література:}

1. WCED. Report of the World Commission on Environment and Development: Our Common Future. 1989. URL: https://sustainabledevelopment.un.org/content / documents/5987our-common-future.pdf (дата звернення 23.06.21).

2. Эколого-экономическое обоснование сбалансированных форм регионального развития в системе "Общество - природа" (Цели, задачи, решения) / Под ред. О.П. Литовки, М.П. Федорова. СПб.: СПбГТУ, 2001. 368 c.

3. Орловська Ю.В., Квактун О.О. Стратегічне управління екологічними інвестиціями: регіональний аспект. Дніпропетровськ: 2011, 280 с.

4. ОрловськаЮ.В., Дригола К.В., Балтакса Д.Г. Теоретичний бекграунд зеленої економіки в рамках світової парадигми сталого розвитку. Економічний простір: збірник наукових праць. № 160. 2020. С. 23-27. URL: http://www.prostir.pdaba.dp.ua/index.php/journal/ article/view/649/631 (дата звернення 25.06.21).

5. Green Policy Platform. Green Sectors. URL: https:/ /www.greengrowthknowledge.org/sectors (дата звернення 25.06.21).

6. Дригола К.В. Міжнародні інструменти фрінансово-економічної політики розвитку зеленої економіки / / Зелена економіка та низьковуглецевий розвиток: міжнародний та національний вимір: матеріали Міжнародної науково-практичної конференції (м. Київ, 4 грудня 2020 р.). Київ: Державна екологічна академія післядипломної освіти та управління, 2020. С. 118-120.

7. Gross Savings of Ukraine. World Bank Statistics. URL: https://data.worldbank.org/indicator/NY.GNS.ICTR.GN.ZS?locations=UA (дата звернення 27.06.21).
8. Державна служба статистики України. URL: http:/ /www.ukrstat.gov.ua/ (дата звернення 27.06.21).

9. Цілі сталого розвитку Україна 2020. URL: http:/ /www.ukrstat.gov.ua/csr_prezent/ukr/st_rozv/publ/ SDGs\%20Ukraine\%202020\%20Monitoring_12.2020ukr.pdf (дата звернення 27.06.21).

10. Sustainable Development Report. Ukraine. URL: https://dashboards.sdgindex.org/profiles/ukraine (дата звернення 27.06.21).

\section{References:}

1. WCED (1989), "Report of the World Commission on Environment and Development: Our Common Future", available at: https://sustainabledevelopment.un.org/ content/documents /5987our-common-future.pdf (Accessed 23.06.21).

2. Litovki, O. P. and Fedorov, M. P. (2001), Jekologojekonomicheskoe obosnovanie sbalansirovannyh form regional'nogo razvitija v sisteme "Obshhestvo - priroda" (Celi, zadachi, reshenija) [Ecological and economic substantiation of balanced forms of regional development in the "Society - nature" system (Goals, tasks, solutions)], SPbGTU, St.Petersburg, Russia.

3. Orlovs'ka, Ju. V. and Kvaktun, O. O. (2011), Strategichne upravlinnja ekologichnymy investycijamy: regional'nyj aspekt [Strategic management of ecological investments: regional aspect], Dnipropetrovs'k, Ukraine.

4. Orlovs'ka, Ju. V. Drygola, K. V. and Baltaksa, D. G. (2020), "Theoretical background of the green economy within the framework of the world paradigm of sustainable development", Ekonomichnyj prostir: zbirnyk naukovyh prac', vol. 160, pp. 23-27, available at: http://www.prostir.pdaba.dp.ua/index.php/journal/article/view /649/ 631 (Accessed 25.06.21).

5. Green Policy Platform (2021), "Green Sectors",, available at: https://www.greengrowthknowledge.org/ sectors (Accessed 25.06.21).

6. Dryhola, K. V. (2020), "International instruments of financial and economic policy of green economy development", Zelena ekonomika ta nyz'kovuglecevyj rozvytok: mizhnarodnyj ta nacional'nyj vymir: materialy Mizhnarodnoi naukovo-praktychnoi konferentsii [Green economy and low-carbon development: international and national dimension. Proceedings from International scientific-practical conference], Derzhavna ekologichna akademija pisljadyplomnoi' osvity ta upravlinnja, Kyiv, Ukraine, 4 December, pp. 118- 120.

7. World Bank Statistics (2021), "Gross Savings of Ukraine", available at: https://data.worldbank.org/ indicator /NY.GNS.ICTR.GN.ZS?locations $=U A$ (Accessed 27.06.21).

8. State Statistics Service of Ukraine (2021), available at: http://www.ukrstat.gov.ua/ (Accessed 27.06.21).

9. State Statistics Service of Ukraine (2020), "Sustainable Development Goals Ukraine 2020", available at: http://www.ukrstat.gov.ua/csr_prezent/ukr/ st_rozv/publ/SDGs \% 20Ukraine \% 202020\%20M̄onitoring_12.2020ukr.pdf (Accessed 27.06.21).

10. Sustainable Development Report (2021), "Ukraine", available at: https://dashboards.sdgindex.org/profiles/ukraine (Accessed 27.06.21). Статтл надійила до редакиї 29.07.2021 p. 